Article type: Original Article

\title{
Molecular phylogenetic analysis of archival tissue reveals the origin of a disjunct southern African-Palaearctic weevil radiation
}

Gerardo Hernández-Vera ${ }^{1}$, Roberto Caldara ${ }^{2}$, Ivo Toševski ${ }^{3,4}$ and Brent C. Emerson ${ }^{1,5}$

${ }^{1}$ Centre for Ecology, Evolution and Conservation, School of Biological Sciences, University

of East Anglia, Norwich NR4 7TJ, UK, ${ }^{2}$ via Lorenteggio 37, 20146 Milan, Italy, ${ }^{3}$ CABI

Europe-Switzerland, 2800 Delémont, Switzerland, ${ }^{4}$ Department of Plant Pests, Institute for

Plant Protection and Environment, Zemun, Serbia, ${ }^{5}$ Island Ecology and Evolution Research

Group, IPNA-CSIC, 38206 La Laguna, Tenerife, Canary Islands, Spain

*Correspondence: Brent Emerson, Island Ecology and Evolution Research Group, IPNA-

CSIC, C/Astrofísico Francisco Sánchez 3, 38206 La Laguna, Tenerife, Canary Islands, Spain

E-mail: bemerson@ipna.csic.es

Running head: Biogeography of a southern African-Palaearctic weevil radiation 


\section{ABSTRACT}

Aim We test three alternative hypotheses for the disjunct Mediterranean-southern African distribution of endophagous weevils within the genera Rhinusa and Gymnetron (Coleoptera: Curculionidae): (1) a Palaearctic origin with dispersal to southern Africa; (2) a southern African origin with dispersal to the Palaearctic; and (3) a widespread ancestral distribution fragmented by vicariance. Divergence times are estimated to provide an approximate temporal framework for the evolution of the group and to evaluate potential palaeogeographical scenarios.

Location Southern Africa, the Mediterranean region, the Palaearctic and eastern Africa. Methods Freshly collected and dry, pinned samples of weevils were used as a source of DNA. Prior genetic information was used to identify short phylogenetically informative amplicons within the 16S ribosomal RNA gene (16S). Phylogenetic reconstructions using Bayesian and maximum likelihood analyses of mitochondrial and nuclear DNA sequence data and molecular dating techniques were used to infer the biogeographical history of Rhinusa and Gymnetron species. A statistical approach to dispersal-vicariance analysis (S-DIVA) was used to further assess biogeographical hypotheses.

Results Successful polymerase chain reaction amplification of targeted short 16S DNA sequences $(150 \mathrm{bp})$ from dry, pinned specimens provided for increased species sampling of Rhinusa and Gymnetron by $230 \%$, greatly expanding species representation from southern Africa. Phylogenetic reconstructions and S-DIVA analyses support a southern African origin for Rhinusa and Gymnetron species. Divergence time estimates suggest southern African and Palaearctic lineages diverged approximately 11.6-7.4 Ma.

Main conclusions Rhinusa and Gymnetron represent a complex of lineages with a shared evolutionary history of range expansions from southern Africa into the Palaearctic. Our results support a late Miocene vicariance scenario, most likely as a result of repeated 
desertification. The use of prior genetic information to identify short phylogenetically informative amplicons offers a useful approach for molecular phylogenetic analyses incorporating archival material.

\section{Keywords}

Archival tissue, Curculionidae, disjunct distribution, dispersal, Palaearctic, phylogeny, southern Africa, vicariance, weevil. 


\section{INTRODUCTION}

Examples of Mediterranean-southern African disjunct distributions are perhaps mostly known in plants, given the floristic affinities shared by these two regions, which comprise two of the five mediterranean-type floras of the world (Cowling et al., 1996). Previous studies have proposed long-distance dispersal as the major cause of this disjunction (Thorne, 1972; Raven, 1973) and, with some exceptions (e.g. McGuire \& Kron, 2005), the most widely accepted hypothesis is a southern African origin with dispersal to the north through an East African corridor (Caujapé-Castells et al., 2001; Coleman et al., 2003; Calviño et al., 2006; del Hoyo et al., 2009). Interestingly, there are very few studies on plant-feeding insects that exhibit similar disjunct distributions, perhaps tracking the ancestral distribution of their host plants (but see Mey, 2006, and Kirk-Spriggs \& McGregor, 2009, for examples in Lepidoptera and Diptera, respectively). Within Coleoptera, proposed explanations for south African-Mediterranean disjunct distributions favour a vicariance scenario (Biondi \& D’Alessandro, 2008; Bologna et al., 2008), acknowledging the possible ecological connections between the southern African and Mediterranean regions in the past via 'arid corridors', as originally described by Balinsky (1962), which are thought to have appeared in eastern Africa since the end of the Miocene (Verdcourt, 1969; Goldblatt, 1978; Jürgens, 1997).

To further investigate disjunct Mediterranean-southern African insect distributions, we focus attention on weevil species of the closely related genera Rhinusa Stephens, 1829 and Gymnetron Schoenherr, 1825, within the tribe Mecinini (Curculionidae: Curculioninae). Adults of this species-rich group range in size from 2 to $5 \mathrm{~mm}$, with representatives in both the Palaearctic and Afrotropical regions. Species of both genera are endophagous parasites whose larvae feed and develop within tissues of plants in the families Scrophulariaceae and Plantaginaceae as recently circumscribed (Olmstead et al., 2001; Albach et al., 2005). The 
genus Rhinusa comprises approximately 40 species following a Palaearctic distribution (Caldara, 2001), feeding on species within the plant families Scrophulariaceae (Verbascum and Scrophularia) and Plantaginaceae (Linaria, Kickxia, Chaenorhinum, Antirrhinum and Misopates) (Caldara et al., 2010). Gymnetron includes approximately 30 species with a Palaearctic distribution and approximately 60 species from the Afrotropical region, of which 55 are known mainly from South Africa and considered to be endemic to this area (Caldara, 2003). All Palaearctic species use plant species from the genus Veronica (Plantaginaceae) as host plants, whereas representatives from the Afrotropical region use species within the family Scrophulariaceae (Hebenstretia, Sutera, Selago, Buddleja, Diascia, Nemesia and Hemimeris) and the genus Anastrabe in the family Stilbaceae (Caldara et al., 2008). Both genera are taxonomically challenging, with very few morphologically informative characters (Caldara et al., 2010) and, until recently, Rhinusa was considered a subgenus within Gymnetron (Caldara, 2001). In a recent revision of the relationships between Mediterranean and southern African species within the subfamily Curculioninae, Caldara et al. (2008) concluded that species from the Palaearctic and Afrotropical regions appear to be very closely related with only a few subtle morphological differences. However, they recognize that it is not currently possible to distinguish between hypotheses of dispersal or vicariance, nor whether these genera may have originated in southern Africa or in the Mediterranean.

To test among competing biogeographical hypotheses for disjunct Mediterranean and southern African insect distributions, we use sequence data from two mitochondrial and three nuclear genomic regions to reconstruct phylogenetic relationships of representatives within Rhinusa and Gymnetron. These taxa represent an ideal example of a focal group that requires a molecular phylogenetic approach to understand the origin of its species diversity; access to many species is, however, limited to archival material, particularly for southern African taxa. Therefore, we maximize our taxonomic and geographical coverage by 
exploiting the use of archival specimens from a pinned, dried collection using a nondestructive approach. We use genetic data sampled from non-archival material within our focal group as prior information for the design of primers to amplify short phylogenetically informative amplicons (SPIAs; $<100 \mathrm{bp}$ ) of the mitochondrial 16S ribosomal RNA gene, for the incorporation of archival material in molecular phylogenetic analyses. We aim to maximize the number of phylogenetically informative sites, while minimizing amplicon length to account for the limitations in amplifying degraded DNA from museum specimens.

Thus, using both archival specimens and freshly collected samples we test three alternative hypotheses for the disjunct Mediterranean-southern African distribution of Gymnetron species: (1) a Palaearctic origin with dispersal to southern Africa; (2) a southern African origin with dispersal to the Palaearctic; and (3) a widespread ancestral distribution fragmented by vicariance. Divergence times are estimated to provide an approximate temporal framework for the evolution of the group and evaluate potential palaeogeographical scenarios.

\section{MATERIALS AND METHODS}

\section{Taxon sampling}

Our sampling strategy was to obtain broad geographical and taxonomic coverage of representatives within Gymnetron and Rhinusa, using freshly collected samples where possible, and augmenting our sampling for material that was harder to obtain using archival specimens (see Appendix S1 in Supporting Information). Sixty-seven specimens were collected in the field, placed in $96-100 \%$ ethanol, and stored at $4{ }^{\circ} \mathrm{C}$ until DNA extraction. Forty-two dry, pinned specimens were used from the personal entomological collection of R. Caldara for DNA extraction from a single leg (see below). Thirty-two species of Rhinusa were sampled (18 field collected and 14 archival), representing approximately $80 \%$ of 
recognized species, including representatives from the three main taxonomic groups proposed by Caldara et al. (2010). Twenty-five species of Gymnetron were sampled (6 fieldcollected and 20 archival; one species - G. villosulum - was sampled both fresh and archivally), representing 8 of the 13 Afrotropical groups proposed by Caldara (2003) and 11 species from the Palaearctic region. One specimen of the genus Cleopomiarus was also included, which is the only genus within the tribe Mecinini apart from Gymnetron to have representatives in both the Palaearctic and Afrotropical regions (Caldara et al., 2008).

\section{DNA extraction}

Field-sampled weevils were punctured through the abdomen and total genomic DNA was extracted from each individual using the DNeasy extraction kit (Qiagen, Hilden, Germany), following the manufacturer's protocol. After DNA extraction, insects were placed again in $96 \%$ ethanol and kept at $4{ }^{\circ} \mathrm{C}$, before subsequent preparation as voucher specimens within the collection of R.C. When using archival specimens, destruction of the sample for DNA extraction has always been a concern, especially for small specimens (Thomas, 1994; Whitfield \& Cameron, 1994), and for arthropods, several methods have been proposed to minimize damage (Gilbert et al., 2007; Rowley et al., 2007). We use a non-destructive approach using a single leg for DNA extraction as suggested by Gilbert et al. (2007). Dry, pinned insects were first left overnight in a humid chamber in order to reduce exoskeleton brittleness and allow manipulation of the appendages. A single posterior leg was then removed under a dissecting microscope and placed in $200 \mu \mathrm{L}$ of DNeasy extraction buffer for overnight incubation at $56^{\circ} \mathrm{C}$, followed by DNA isolation as for non-archival samples. DNA-extracted appendages were recovered and remounted with their corresponding specimen on a new entomological card (Appendix S2: Fig. S1). 


\section{PCR amplification and sequencing reactions}

Two mitochondrial [cytochrome $c$ oxidase subunit II (COII) and 16S ribosomal RNA (16S)] and three nuclear gene fragments [elongation factor-1 $\alpha(E F-1 \alpha)$, arginine kinase $(A K)$ and $18 \mathrm{~S}$ ribosomal RNA (18S)] were used. The primers used for each gene are described in Appendix S3. For all loci, polymerase chain reactions (PCR) were performed with BioTaq DNA polymerase (Bioline, London, UK) with $1 \times \mathrm{NH}_{4}$ buffer, 3.5-5.0 $\mathrm{mM} \mathrm{MgCl}, 0.2 \mathrm{mM}$ each dNTP, $0.2-0.4 \mu \mathrm{M}$ each primer, $0.5 \mathrm{U}$ of Taq polymerase and $1-5 \mu \mathrm{L}$ of DNA template in a $25-\mu \mathrm{L}$ final volume. PCR cycles were carried out using the following thermal profile for the $C O I I$ and $A K$ gene fragments: $95^{\circ} \mathrm{C}$ for $3 \mathrm{~min}, 33$ and 37 cycles respectively at $95{ }^{\circ} \mathrm{C}$ for $1 \mathrm{~min}, 48{ }^{\circ} \mathrm{C}$ for $1 \mathrm{~min}, 72{ }^{\circ} \mathrm{C}$ for $1 \mathrm{~min}$, and a final extension at $72{ }^{\circ} \mathrm{C}$ for $3 \mathrm{~min}$. For $E F-1 \alpha$, $16 S$ and $18 \mathrm{~S}$ genes, two different touchdown profiles (Don et al., 1991) were used. For EF$1 \alpha$ and $16 S$, the programme comprised $94{ }^{\circ} \mathrm{C}$ for $1 \min 30 \mathrm{~s}, 10$ cycles at $94{ }^{\circ} \mathrm{C}$ for $45 \mathrm{~s}$, $58^{\circ} \mathrm{C}$ for $1 \mathrm{~min}, 72{ }^{\circ} \mathrm{C}$ for $1 \mathrm{~min}$, decreasing the annealing temperature by $1{ }^{\circ} \mathrm{C}$ every cycle, then 35 cycles at $94{ }^{\circ} \mathrm{C}$ for $45 \mathrm{~s}, 48^{\circ} \mathrm{C}$ for $1 \mathrm{~min}, 72^{\circ} \mathrm{C}$ for $1 \mathrm{~min}$, and $72{ }^{\circ} \mathrm{C}$ for $3 \mathrm{~min}$ as a final extension. For the $18 S$ fragment, the programme comprised $95^{\circ} \mathrm{C}$ for $3 \mathrm{~min}, 8$ cycles at $94{ }^{\circ} \mathrm{C}, 54{ }^{\circ} \mathrm{C}$ and $72{ }^{\circ} \mathrm{C}$ for $1 \mathrm{~min}$ at each temperature, decreasing the annealing temperature by $1{ }^{\circ} \mathrm{C}$ every cycle, then 28 cycles at $94{ }^{\circ} \mathrm{C}, 46^{\circ} \mathrm{C}$ and $72{ }^{\circ} \mathrm{C}$ for $1 \mathrm{~min}$ at each temperature and a final extension at $72{ }^{\circ} \mathrm{C}$ for $2 \mathrm{~min}$. Sequences were generated with a PerkinElmer ABI3700 automated sequencer, using the BigDye terminator reaction protocol (v3.1 PerkinElmer, Cheshire, UK) in a $10-\mu \mathrm{L}$ final volume. For the COII, $16 S, A K$ and $18 S$ gene fragments, sequences were obtained with the forward primer only, except in few cases which required sequencing in both directions because of low-quality chromatograms. All of the $E F$ $1 \alpha$ sequences were obtained with forward and reverse primers because of the presence of an intron region with indels. 


\section{SPIAs primer design, PCR amplification and sequencing}

Based on the alignment of gene partitions from non-archival samples, we identified two adjacent variable regions of $95 \mathrm{bp}$ and $55 \mathrm{bp}$ within the mitochondrial $16 \mathrm{~S}$ gene, flanked by comparatively conserved motifs. We designed primers spanning each of these amplicons, also including representative sequences from GenBank within the family Curculionidae to maximize the broad taxonomic utility of these primers, including the following genera: Anthonomus, Brachonyx, Curculio, Eutoxus and Tychius. We also included Tribolium from the family Tenebrionidae. For one of the 16 S SPIAs, the forward PCR primer included an M13 adaptor oligonucleotide (Appendix S3), and the adaptor was used as a sequencing primer to improve sequence read quality immediately after the $3^{\prime}$ end of the primer. The two $16 S$ amplicons were PCR amplified with the following conditions: $95^{\circ} \mathrm{C}$ for $5 \mathrm{~min} ; 40$ cycles at $95{ }^{\circ} \mathrm{C} ; 45^{\circ} \mathrm{C}$ and $72{ }^{\circ} \mathrm{C}$ for $20 \mathrm{~s}$; and a final extension at $72{ }^{\circ} \mathrm{C}$ for $5 \mathrm{~min}$. To control for contamination, full precautions were taken; these included the use of a PCR hood workstation with a 15-minute UV-light sterilization step, dedicated PCR pipettes, filtered tips, and the inclusion of multiple negative controls. All short $16 S$ amplicons were sequenced in both directions, and in some cases resequenced from an independent PCR reaction to corroborate accuracy.

\section{Phylogenetic analyses}

All sequences were automatically aligned using the CLUSTALW algorithm, as implemented in BIOEDIT 7.0.9 (Hall, 1999), with further manual alignment. For $E F-1 \alpha$, forward and reverse sequences were first assembled as contigs, and the intron region removed due to the inability to align it unambiguously. Sequence properties for each individual gene partition were assessed using MEGA 4.0.1 (Tamura et al., 2007). Phylogenetic analyses were performed for individual partitions, and for a concatenated alignment of nuclear and 
mitochondrial sequences. For the latter, analyses were performed using two data sets. The first data set consisted of ingroup taxa with complete sampling of the five gene partitions. The second data set consisted of the first data set with the addition of archival specimens sampled for the SPIAs. Bayesian analyses were performed with the parallel version of MrBAYES 3.1 (Huelsenbeck \& Ronquist, 2001; Ronquist \& Huelsenbeck, 2003) using the substitution models selected by JMODELTEST (Posada, 2008) for each partition, with priors set to the default values as recommended by Ronquist et al. (2005). Settings for each gene partition in the individual analyses were as follows: two simultaneous runs (each with two chains) of the Markov chain Monte Carlo (MCMC) for five million generations, with a sampling frequency of 100 generations, a heating parameter value of $0.02-0.05$ (decreased from the default value 0.2 to improve swapping of states between the heated and cold chains) and a relative burn-in of $25 \%$. Summaries from the stationary distribution of the sampled parameter values and sampled trees were obtained, as well as a majority-rule consensus tree with posterior probabilities for each bipartition. For concatenated sequence analyses (five gene partitions) with and without archival specimens, we also used two independent runs but with four Markov chains each, to optimize convergence for large data sets, as suggested by Ronquist et al. (2005), and 20 million generations, sampling every 1000 generations. To determine stationarity of the MCMC chains, variation in log-likelihood scores was examined graphically using the program TRACER 1.5 (Rambaut \& Drummond, 2007); the final standard deviation of split frequencies was $\leq 0.01$ in all analyses. Maximum likelihood (ML) analyses were performed with the parallel version of RAxML 7.0.4 (Stamatakis, 2006) for the data set of five gene partitions with and without archival specimens sampled for the SPIAs. A partitioned model was used where each genetic marker was assigned a separate $G T R+I+G$ model. One thousand heuristic searches were executed using the default settings to find the ML tree. Branch support was estimated from 1000 replicates using the standard bootstrap 
procedure as implemented in RAXML (Stamatakis et al., 2008). Both Bayesian and ML analyses were conducted on the High Performance Computing Cluster at the University of East Anglia.

\section{Assessing the phylogenetic placement of archival material sampled for SPIAs}

Phylogenetic placement of the archival taxa sampled for SPIAs was assessed with two approaches. First, we performed a Bayesian analysis of non-archival specimens with the concatenated alignment of five gene partitions. Nucleotide data for selected taxa representing a range of divergences from sister lineages were reduced or 'trimmed' to the SPIA partitions. We then compared the phylogenetic placement of these character-reduced taxa within the phylogeny with their placement in analyses using the full set of characters. As a second approach, Bayes factors were used to compare the likelihoods of models with enforced monophyly at key nodes of interest including archival specimens sampled for the SPIAs, against models without such constraints.

\section{Estimation of divergence times}

In the absence of geological or fossil calibration points to estimate divergence times, we take a Bayesian approach as implemented in BEAST 1.4.8 (Drummond \& Rambaut, 2007) using a relaxed molecular clock to estimate the age of the most recent common ancestor (MRCA) of nodes of interest representing divergences between southern African and Palaearctic lineages. We applied a mean pancrustacean $C O I I$ rate estimate of $3.05 \%$ pairwise divergence per million years, based on previous work showing the mean substitution rate of Coleoptera to approximate the mean rate across the Pancrustacea (Cicconardi et al., 2010). The estimated age of the root of the COII tree was then used as prior information for rate calibration of the SPIAs. The validity of applying the COII mean substitution rate to the $16 \mathrm{~S}$ 
gene was assessed by comparison of the uncorrected pairwise distances of both genes which are closely correlated $(r=0.74)$ (see Appendix S2: Fig. S2).

\section{Reconstruction of ancestral ranges}

To further evaluate the biogeographical patterns observed in the phylogeny and infer ancestral ranges, we used statistical dispersal-vicariance analysis as implemented in the software S-DIVA (Yu et al., 2010). This program incorporates the methods of Nylander et al. (2008) and Harris \& Xiang (2009) to account for phylogenetic uncertainty - and uncertainty in dispersal-vicariance analysis (DIVA) optimization - using a nonparametric empirical Bayesian approach. Statistical support for ancestral range reconstructions is determined by averaging the frequencies of an ancestral range at a node over a set of trees (Yu et al., 2010). We used the 20,000 trees sampled from the Bayesian analysis of the data set of five gene partitions including archival specimens with 5000 trees discarded as burn-in. The number of maximum areas was set to two, reflecting the ingroup's number of defined areas of distribution - (A) southern Africa and (B) Palaearctic.

\section{RESULTS}

The five gene fragments were amplified and sequenced for 56 of the 67 field-collected samples (see Appendix S1 for GenBank accession numbers). The 10 samples of $G$. rotundicolle and the sample of $G$. rostellum consistently failed to amplify for any gene fragment, and were subsequently found to have been stored in denatured ethanol. They were consequently amplified using the same protocol applied to archival samples. Across the 56 individuals sequenced for the five gene partitions, only five samples present some missing sequence data due to poor read quality in some regions of the chromatograms. Sequence variation within each gene partition is detailed in Table 1 . The combined data of five gene 
partitions contained 3943 nucleotides, of which 885 sites were variable and 19\% were parsimony-informative. The full DNA sequence data matrix including SPIA sequences is available in TreeBase (http://treebase.org/, accession number S13611).

\section{SPIA primer design, PCR amplification and sequencing}

Successful PCR amplification was achieved for both SPIAs for all 42 archival samples and the 11 samples in denatured ethanol. Five archival samples yielded comparatively weak PCR products, and did not generate readable sequence chromatograms. The remaining 37 samples yielded readable sequence chromatograms for both SPIAs (Appendix S1), increasing our species sampling with the addition of 11 and 17 taxa from Rhinusa and Gymnetron, respectively, and greatly expanding species representation from southern Africa.

\section{Phylogenetic analyses and assignment of archival specimens}

Analyses of individual gene partitions essentially recovered the same tree topology, but with different degrees of phylogenetic resolution. Bayesian and ML analyses of the data set of five gene partitions, without archival samples, recovered the same robustly supported phylogeny (Fig. 1), revealing neither Rhinusa nor Gymnetron to be monophyletic, but with phylogenetic relationships among Rhinusa species broadly in agreement with the taxonomy of Rhinusa based on morphological characters. The same phylogenetic relationships among non-archival samples were derived from Bayesian and ML analyses when the 16S SPIAs were included within the alignment of the five gene partitions (Fig. 2), with the single exception of G. melanarium being placed basally within clade $\mathrm{G}$ in the Bayesian analysis. Bayesian and ML analyses with the inclusion of the $16 \mathrm{~S}$ SPIAs also resulted in the identical phylogenetic placements of the archival specimens (Fig. 2), with the single exception of clade I being placed as the sister group to clade L in the ML analysis. 
Despite the limited amount of nucleotide data $(150 \mathrm{bp})$, relatively high posterior probability (PP) and/or bootstrap support (BS) values were observed for the placement of some archival specimens. Two southern African taxa, Gymnetron perrinae and G. bisignatum, are united as sister taxa with $\mathrm{PP}=1$ and $\mathrm{BS}=93 \%$. Rhinusa exigua is placed as the sister lineage to the clade of $R$. antirrhini/R. florum with $\mathrm{PP}=0.85$ and $\mathrm{BS}=78 \%$. Rhinusa brisouti is placed as the sister lineage to $R$. linariae with $\mathrm{PP}=0.90$ and $\mathrm{BS}=75 \%$. Rhinusa moroderi is placed as the sister lineage to $R$. tetra with $\mathrm{PP}=0.98$ and $\mathrm{BS}=85 \%$. Rhinusa comosa is placed as the sister lineage to $R$. verbasci with $\mathrm{PP}=1$ and $\mathrm{BS}=98 \%$. Gymnetron minimum and G. pauxillum are united as sister species with $\mathrm{PP}=1$ and $\mathrm{BS}=$ 99\%. Finally, G. aequale and G. veronicae are united as sister taxa with $\mathrm{PP}=1$ and $\mathrm{BS}=$ 100\%. Twenty-four archival specimens are placed within clades A, B, E, F and G (Fig. 2), which were also inferred by the analysis of the five-gene data set without archival specimens (Fig. 1). The remaining 13 samples, plus the 10 samples of G. rotundicolle and the sample of G. rostellum, were placed outside the lineages and clades defined in Fig. 1.

To examine how placements might be influenced by limited nucleotide data, a Bayesian analysis of the concatenated alignment of the five genes without archival samples was performed with the sequences of $R$. linariae, $R$. vestita and G. piceum trimmed to represent the $16 S$ SPIAs. In the case of $R$. linariae and $R$. vestita, representing moderate and intermediate divergences, respectively, from their sister lineages, they were both assigned to their correct clades, but with some slight topological changes. A single branch arrangement places $R$. linariae as a sister lineage to $R$. griseohirta within clade A (see Appendix S2: Fig. $\mathrm{S} 3$ ). Two branch arrangements result in a more derived phylogenetic position for $R$. vestita within clade B. In the more extreme case of divergence from a sister lineage, the phylogenetic placement of G. piceum was substantially altered (Fig. S3). These results indicate that while approximate phylogenetic placement can be achieved with limited SPIA 
data, exact placements might not be reliably inferred. Thus, our phylogenetic results clearly support deep genetic divergences across southern African taxa, although the specific relationships of southern African lineages to Palaearctic lineages and the basal divergences of several southern African lineages require further assessment. To achieve this, we carried out Bayes-factor tests to compare the harmonic means of likelihood values of (1) models with enforced monophyly for each of nodes I-IV (Fig. 2) that represent the MRCAs of southern African and Palaearctic lineages, and (2) a model enforcing the monophyly of clades A-L, excluding all remaining southern African species, against models without the constraint of monophyly. Applying the guidelines of Kass \& Raftery (1995), we obtained very strong support for the monophyly of nodes II-IV, and the clade comprising groups A-L (ln Bayes factor $>10$ ), while only moderate support was obtained for the monophyly of node I $(2<\ln$ Bayes factor $<10)$.

\section{Divergence time estimates}

BEAST analyses calibrated with the evolutionary rate for the mtDNA COII gene generated a mean estimate of 26.7 million years ago (Ma) for the MRCA of Gymnetron and Rhinusa, with a 95\% highest posterior density (HPD) interval of 21.2-32.5 million years (Ma). This age estimate was used as prior information to calibrate the corresponding node of the tree containing both archival and non-archival samples (Fig. 2), to estimate the approximate divergence times of southern African Gymnetron lineages from Palaearctic Gymnetron and Rhinusa lineages with $16 S$ SPIA sequence data. We imposed a normal distribution for the root age with a mean of $26.7 \mathrm{Ma}$ and a standard deviation of $7 \mathrm{Myr}$, allowing a 95\% probability distribution for sampling of 15-35 Ma, an interval that includes the 95\% HPD estimated with mtDNA COII sequence data. Prior information for the $16 S$ SPIA substitution rate was also incorporated. We estimated a range of $16 \mathrm{~S}$ SPIA rates by fixing the MRCA of 
Gymnetron and Rhinusa to be (1) $21.2 \mathrm{Ma}$, representing the lower $2.5 \%$ posterior probability value estimated from mtDNA COII data, and (2) $32.5 \mathrm{Ma}$, representing the upper $2.5 \%$ posterior probability value. Based on the resulting mean rate estimates from these calibrations of 0.0047 and 0.018 substitutions per site per million years, we applied a normal distribution for the SPIA mutation rate with a mean of 0.01 and a standard deviation of 0.005, thus incorporating our estimated range within the 95\% HPD interval. Normal distributions were chosen as prior parametric distributions because they allow bidirectional uncertainty in the calibration estimates (Ho \& Phillips, 2009). Ages for four nodes corresponding to divergences between southern African and Palaearctic lineages were estimated (Fig. 2, Table 2), yielding broad HPDs, reflecting the broad prior root age and substitution-rate distributions that we allowed the analysis to sample from. However, the mean age estimates for all four divergence events range between 11.6 and 7.4 Ma, suggesting a late Miocene divergence between Palaearctic and southern African lineages.

\section{Reconstruction of ancestral ranges}

The relative probabilities of alternative ancestral ranges mapped onto the two most basal nodes of the phylogenetic tree that included the archival specimens suggest a southern African origin for Rhinusa and Gymnetron, with values higher than 60\% (Fig. 2). Subsequent vicariant events across ancestral ranges that extended to include both southern Africa and the Palaearctic were inferred for nodes representing the MRCAs of southern African and Palaearctic lineages (nodes I-IV; Fig. 2).

\section{DISCUSSION}

\section{Phylogenetic analyses and assignment of archival specimens}


Analyses of Rhinusa and Gymnetron species sampled for all five gene partitions resulted in a robust phylogeny, recovering four monophyletic groups largely in agreement with a proposed taxonomy based on adult morphological characters (Caldara et al., 2010). The single major difference from conventional taxonomic classification is that Gymnetron and Rhinusa are not reciprocally monophyletic. When the $16 S$ SPIAs from archival specimens were included in the data matrix, Bayesian and ML analyses recovered essentially the same tree topology, with most archival samples falling within clades defined by the complete matrix of five genes, largely in agreement with prior taxonomic expectations (Caldara, 2003, 2008; Caldara et al., 2010). High support values for the placement of several archival specimens, obtained in both Bayesian and ML analyses, suggest that phylogenetic placement can in some cases be achieved with a high degree of confidence using SPIAs. This is consistent with previous findings that show there is no relationship between character completeness of a taxon, and the level of support for its placement within a phylogeny (Wiens et al., 2005). However, for more divergent archival lineages within a particular clade, phylogenetic placement may be less reliably inferred, as revealed by our Bayesian analyses with sequences for selected taxa reduced to the 150 nucleotides of the $16 S$ SPIAs. Thus, for nodes of relevance to our biogeographical hypotheses that lack high support from both Bayesian posterior probabilities and ML bootstrap values, we have applied Bayes-factor analyses to test hypotheses of monophyly, and applied statistical dispersal-vicariance analyses, allowing us to take phylogenetic uncertainty into account.

Although several authors have suggested that including taxa with a high proportion of missing characters is potentially problematic for phylogenetic reconstruction (Huelsenbeck, 1991; Wilkinson, 1995; Kearney, 2002; Hartmann \& Vision, 2008), our results are largely in agreement with evidence suggesting that as long as taxa with missing characters bear sufficient phylogenetically informative data, and the overall number of 
characters included in the analysis is not unusually low $(\leq 100)$, highly incomplete taxa can be accurately placed within a phylogeny (Wiens \& Morrill, 2011; and references therein). It has previously been suggested that parametric methods, such as ML and Bayesian analyses, perform well in placing taxa with missing characters onto individual branches with high support values by extrapolating topological and branch length inferences from one group of characters to another (Philippe et al., 2004; Fulton \& Strobeck, 2006; Wiens \& Moen, 2008; Wolsan \& Sato, 2010). Using a sequence data matrix of 3943 bp as a 'scaffold' on which the missing-character taxa could be placed (Wiens et al., 2005; Wiens, 2006), we have shown that the geographical and taxonomic scope of phylogenetic studies can be augmented with archival specimens by the targeted amplification of short phylogenetically informative DNA regions.

\section{Historical biogeography of Rhinusa and Gymnetron}

Southern African taxa are characterized by deep genetic divergences, several lineages of which form monophyletic groups with Palaearctic Rhinusa and Gymnetron lineages. Bayesfactor analyses support a phylogenetic topology with basal lineages of southern African origin. Following the reasoning of Bremer (1992) and Hausdorf (1998), plesiomorphic areas in a cladogram are more likely to be part of the ancestral range than apomorphic areas; likewise, areas represented on more than one branch have a higher probability of being part of the ancestral area than areas less represented. Thus, the basal placement of three southern African lineages within the phylogeny (G. gossypinus, G. bisignatum + G. perrinae, and G. buddleiae) supports southern Africa as the ancestral area from where extant Gymnetron and Rhinusa species diversity is derived. Congruent with this hypothesis, results from the S-DIVA analysis show higher relative probabilities for southern Africa as the ancestral range at the two most basal nodes in the phylogeny (Fig. 2). 
One of the more likely opportunities for large-scale range expansions from Africa into the Palaearctic, or the Palaearctic into Africa, probably occurred during the early-mid Miocene boundary (c. $17 \mathrm{Ma}$ ), when a land connection formed between Europe and Africa after the closure of the Tethys Sea (Levyns, 1964; McGuire \& Kron, 2005). Several authors have suggested the existence of geographical and ecological routes connecting southern and eastern Africa with the Mediterranean region in the past that would have facilitated range expansions of plants and animals between the Palaearctic and Afrotropical regions. Evidence supporting the presence of an 'arid corridor' connecting southern, eastern and north-eastern African areas prior to the end of the Miocene has been documented for many plant groups (Verdcourt, 1969; Goldblatt, 1978; Jürgens, 1997; Caujapé-Castells et al., 2001; Coleman et al., 2003; Thiv et al., 2011) and animals (Balinsky, 1962; La Greca, 1990; Freitag \& Robinson, 1993; Herron et al., 2005) exhibiting disjunct distributions. Severance of this corridor has been linked to late-Miocene uplift and associated rifting in Africa and major climatic changes during the late Miocene (Chorowicz, 2005; Schuster et al., 2006). Both our age estimates and S-DIVA analyses are consistent with this scenario. Although our analyses yielded broad HPD intervals, reflecting the broad prior root age and substitution rate distributions employed, mean estimated divergence times between Palaearctic and southern African lineages (nodes I-IV; Fig. 2) suggest that divergences most probably occurred within the late Miocene (c. 11.6-7.4 Ma). S-DIVA analysis inferred vicariant events and an ancestral range including both southern Africa and the Palaearctic regions at nodes representing the MRCA of southern African and Palaearctic lineages (nodes I-IV; Fig. 2). Further support for the east African arid corridor hypothesis comes from the presence of several Gymnetron species in eastern Africa (Caldara et al., 2008), suggesting more northerly African relicts of an ancestral range once stretching north from southern Africa to East Africa. The land connection between the African and Asian plates would have facilitated range expansion 
further north into the Mediterranean and European regions, with new vegetation zones representing the opportunity to exploit new niches. Climate-mediated vicariant events would have acted to fragment a once-continuous range as conditions became progressively drier after the mid-Miocene (Axelrod \& Raven, 1978), with periods of greater aridity, particularly for the eastern region of Africa, in the late Miocene (c. $6 \mathrm{Ma}$ ), the Pliocene (c. $3 \mathrm{Ma})$, and near the Pliocene-Pleistocene boundary (<2 Ma) (deMenocal, 1995; Bobe, 2006). The importance of these climatic changes as vicariant events has been demonstrated for different groups of animals (Leakey et al., 1996; Douady et al., 2003) and plants (del Hoyo et al., 2009; Thiv et al., 2010), including examples of mid-to-late Miocene radiations in the genera Nemesia (Datson et al., 2008) and Linaria (Fernández-Mazuecos \& Vargas, 2011), two host plant genera utilized by Gymnetron and Rhinusa, respectively.

Within Coleoptera, our results are in accordance with previously proposed vicariance scenarios for Mediterranean-southern African disjunct distributions of beetles in the families Meloidae (Bologna et al., 2008) and Nitidulidae (Audisio et al., 2008). For both these groups, repeated desertification phenomena since the Miocene and through the Pliocene and Pleistocene are suggested to have fragmented probable ancestral distributions extending between European-Mediterranean and eastern/southern African areas. It should be noted that our divergence-date estimates may overestimate the timing of divergence between southern African and Palaearctic lineages, due to incomplete species sampling and species extinctions. Additionally, our analyses have incorporated broad parametric prior distributions to account for uncertainty both in tree root age, and in molecular evolutionary rate, yielding wide HPD intervals for our estimated divergence times. However, the broad consistency across our four mean age estimates, together with ancestral range reconstruction, argue for a southern African origin of species diversity within Gymnetron and Rhinusa, with subsequent range expansion into the Palaearctic followed by late-Miocene vicariance and divergence 
between southern African Gymnetron lineages and lineages of Gymnetron and Rhinusa in the Palaearctic.

\section{CONCLUSIONS}

Rhinusa and Gymnetron are not monophyletic with respect to each other, and present multiple lineages that are disjunct between southern Africa and the Palaearctic. We were able to test biogeographical hypotheses for the origin of their southern African-Palaearctic disjunct distribution by incorporating many species only available as archival material, using prior genetic information to identify short phylogenetically informative amplicons for their approximate phylogenetic placement. Molecular phylogenetic data provide support for a southern African origin, with the earliest divergence within the group estimated to date back to approximately $27 \mathrm{Ma}$, and subsequent range expansion into the Palaearctic. The timing of the northward range expansion of the group into the Palaearctic is not discernible from the tree topology, but would have been facilitated by a Miocene 'arid corridor', suggested to have connected southern, eastern and north-eastern African areas. Molecular data permit estimation of the approximate timings of four vicariant events between Palaearctic and southern African lineages, which are consistent with an inferred late-Miocene disruption of the arid corridor as a consequence of geological and climatic changes within this period. 


\section{ACKNOWLEDGEMENTS}

This research was funded by Consejo Nacional de Ciencia y Tecnología (CONACYT)

Mexico and in part by Grant III43001 (Ministry of Education and Science of the Republic of

Serbia). Bayesian and maximum-likelihood analyses were carried out on the High

Performance Computing Cluster supported by the Research Computing Service at the

University of East Anglia. We are grateful to Mark Carine and three anonymous referees for useful suggestions to improve the manuscript. 


\section{REFERENCES}

Albach, D.C., Meudt, H.M. \& Oxelman, B. (2005) Piecing together the "new" Plantaginaceae. American Journal of Botany, 92, 297-315.

Audisio, P., De Biase, A., Kirk-Spriggs, A.H., Cline, A.R., Trizzino, M., Antonini, G. \& Mancini, E. (2008) Molecular biogeography of Mediterranean and southern African disjunctions as exemplified by pollen beetles of the Meligethes planiusculus speciesgroup and related taxa (Coleoptera: Nitidulidae; Meligethinae). Biogeographia, 29, $45-65$.

Axelrod, D.I. \& Raven, P.H. (1978) Late Cretaceous and Tertiary vegetation history of Africa. Biogeography and ecology of southern Africa (ed. by M.J.A. Werger), pp. 77130. W. Junk, The Hague.

Balinsky, B.I. (1962) Patterns of animal distribution of the African continent. Annals of the Cape Provincial Museum, 2, 299-310.

Biondi, M. \& D’Alessandro, P. (2008) Taxonomical revision of the Longitarsus capensis species-group: an example of Mediterranean-southern African disjunct distributions (Coleoptera: Chrysomelidae). European Journal of Entomology, 105, 719-736.

Bobe, R. (2006) The evolution of arid ecosystems in eastern Africa. Journal of Arid Environments, 66, 564-584.

Bologna, M.A., Di Giulio, A. \& Pitzalis, M. (2008) Systematics and biogeography of the genus Actenodia (Coleoptera: Meloidae: Mylabrini). Systematic Entomology, 33, $319-360$.

Bremer, K. (1992) Ancestral areas: a cladistic reinterpretation of the center of origin concept. Systematic Biology, 41, 436-445. 
Caldara, R. (2001) Phylogenetic analysis and higher classification of the tribe Mecinini (Coleoptera: Curculionidae, Curculioninae). Koleopterologische Rundschau, 71, 171210.

Caldara, R. (2003) Revisione dei Gymnetron della Regione Afrotropicale (Coleoptera Curculionidae). Memorie della Società Entomologica Italiana, 82, 87-272.

Caldara, R. (2008) Revisione delle specie Paleartiche del genere Gymnetron (Insecta, Coleoptera: Curculionidae). Aldrovandia, 4, 27-103.

Caldara, R., Colonnelli, E. \& Osella, G. (2008) Curculionidae Curculioninae: relationships between Mediterranean and southern African species (Coleoptera). Biogeographia, 29, 133-156.

Caldara, R., Sassi, D. \& Toševski, I. (2010) Phylogeny of the weevil genus Rhinusa Stephens based on adult morphological characters and host plant information (Coleoptera: Curculionidae). Zootaxa, 2627, 39-56.

Calviño, C.I., Tilney, P.M., van Wyk, B.-E. \& Downie, S.R. (2006) A molecular phylogenetic study of southern African Apiaceae. American Journal of Botany, 93, $1828-1847$.

Caujapé-Castells, J., Jansen, R.K., Membrives, N., Pedrola-Monfort, J., Montserrat, J.M. \& Ardanuy, A. (2001) Historical biogeography of Androcymbium Willd. (Colchicaceae) in Africa: evidence from cpDNA RFLPs. Botanical Journal of the Linnean Society, 136, 379-392.

Chorowicz, J. (2005) The East African rift system. Journal of African Earth Sciences, 43, $379-410$.

Cicconardi, F., Nardi, F., Emerson, B.C., Frati, F. \& Fanciulli, P.P. (2010) Deep phylogeographic divisions and long-term persistence of forest invertebrates in the North-Western Mediterranean basin. Molecular Ecology, 19, 386-400. 
Coleman, M., Liston, A., Kadereit, J.W. \& Abbott, R.J. (2003) Repeat intercontinental dispersal and Pleistocene speciation in disjunct Mediterranean and desert Senecio (Asteraceae). American Journal of Botany, 90, 1446-1454.

Cowling, R.M., Rundel, P.W., Lamont, B.B., Arroyo, M.K. \& Arianoutsou, M. (1996) Plant diversity in mediterranean-climate regions. Trends in Ecology and Evolution, 11, $362-366$.

Datson, P.M., Murray, B.G. \& Steiner, K.E. (2008) Climate and the evolution of annual/perennial life-histories in Nemesia (Scrophulariaceae). Plant Systematics and Evolution, 270, 39-57.

deMenocal, P.B. (1995) Plio-Pleistocene African climate. Science, 270, 53-59.

Don, R.H., Cox, P.T., Wainwright, B.J., Baker, K. \& Mattick, J.S. (1991) ‘Touchdown’ PCR to circumvent spurious priming during gene amplification. Nucleic Acids Research, 19, 4008.

Douady, C.J., Catzeflis, F., Raman, J., Springer, M.S. \& Stanhope, M.J. (2003) The Sahara as a vicariant agent, and the role of Miocene climatic events, in the diversification of the mammalian order Macroscelidea (elephant shrews). Proceedings of the National Academy of Sciences USA, 100, 8325-8330.

Drummond, A.J. \& Rambaut, A. (2007) BEAST: Bayesian evolutionary analysis by sampling trees. BMC Evolutionary Biology, 7, 214.

Fernández-Mazuecos, M. \& Vargas, P. (2011) Historical isolation versus recent long-distance connections between Europe and Africa in bifid toadflaxes (Linaria sect. Versicolores). PLoS ONE, 6, e22234.

Freitag, S. \& Robinson, T.J. (1993) Phylogeographic patterns in mitochondrial DNA of the ostrich (Struthio camelus). The Auk, 110, 614-622. 
Fulton, T.L. \& Strobeck, C. (2006) Molecular phylogeny of the Arctoidea (Carnivora): effect of missing data on supertree and supermatrix analyses of multiple gene data sets. Molecular Phylogenetics and Evolution, 41, 165-181.

Gilbert, M.T.P., Moore, W., Melchior, L. \& Worobey, M. (2007) DNA extraction from dry museum beetles without conferring external morphological damage. PLoS ONE, 2, e272.

Goldblatt, P. (1978) Analysis of the flora of southern Africa: its characteristics, relationships, and origins. Annals of the Missouri Botanical Garden, 65, 369-346.

Hall, T.A. (1999) BioEdit: a user-friendly biological sequence alignment editor and analysis program for windows 95/98/NT. Nucleic Acids Symposium Series, 41, 95-98.

Harris, A.J. \& Xiang, Q-Y. (2009) Estimating ancestral distributions of lineages with uncertain sister groups: a statistical approach to Dispersal-Vicariance Analysis and a case using Aesculus L. (Sapindaceae) including fossils. Journal of Systematics and Evolution, 47, 349-368.

Hartmann, S. \& Vision, T.J. (2008) Using ESTs for phylogenomics: can one accurately infer a phylogenetic tree from a gappy alignment? BMC Evolutionary Biology, 8, 95.

Hausdorf, B. (1998) Weighted ancestral area analysis and a solution of the redundant distribution problem. Systematic Biology, 47, 445-456.

Herron, M.D., Waterman, J.M. \& Parkinson, C.L. (2005) Phylogeny and historical biogeography of African ground squirrels: the role of climate change in the evolution of Xerus. Molecular Ecology, 14, 2773-2788.

Ho, S.Y.W. \& Phillips, M.J. (2009) Accounting for calibration uncertainty in phylogenetic estimation of evolutionary divergence times. Systematic Biology, 58, 367-380. 
del Hoyo, A., García-Marín, J.L. \& Pedrola-Monfort, J. (2009) Temporal and spatial diversification of the African disjunct genus Androcymbium (Colchicaceae). Molecular Phylogenetics and Evolution, 53, 848-861.

Huelsenbeck, J.P. (1991) When are fossils better than extant taxa in phylogenetic analysis? Systematic Zoology, 40, 458-469.

Huelsenbeck, J.P. \& Ronquist, F. (2001) MRBAYES: Bayesian inference of phylogenetic trees. Bioinformatics, 17, 754-755.

Jürgens, N. (1997) Floristic biodiversity and history of African arid regions. Biodiversity and Conservation, 6, 495-514.

Kass, R.E. \& Raftery, A.E. (1995) Bayes factors. Journal of the American Statistical Association, 90, 773-795.

Kearney, M. (2002) Fragmentary taxa, missing data, and ambiguity: mistaken assumptions and conclusions. Systematic Biology, 51, 369-381.

Kirk-Spriggs, A.H. \& McGregor, G.K. (2009) Disjunctions in the Diptera (Insecta) fauna of the Mediterranean Province and southern Africa and a discussion of biogeographical considerations. Transactions of the Royal Society of South Africa, 64, 32-52.

La Greca, M. (1990) Considerazioni sul popolamento animale dell'Africa Orientale. Biogeographia, 14, 541-578.

Leakey, M.G., Feibel, C.S., Bernor, R.L., Harris, J.M., Cerling, T.E., Stewart, K.M., Storrs, G.W., Walker, A., Werdelin, L. \& Winkler, A.J. (1996) Lothagam: a record of faunal change in the late Miocene of East Africa. Journal of Vertebrate Paleontology, 16, $556-570$.

Levyns, M.R. (1964) Migrations and origin of the Cape Flora. Transactions of the Royal Society of South Africa, 37, 85-107. 
McGuire, A.F. \& Kron, K.A. (2005) Phylogenetic relationships of European and African Ericas. International Journal of Plant Sciences, 166, 311-318.

Mey, W. (2006) Revision of the genus Phyllobrostis Staudinger, 1859 (Lepidoptera, Lyonetiidae). Deutsche Entomologische Zeitschrift, 53, 114-147.

Nylander, J.A.A., Olsson, U., Alström, P. \& Sanmartín, I. (2008) Accounting for phylogenetic uncertainty in biogeography: a Bayesian approach to dispersalvicariance analysis of the thrushes (Aves: Turdus). Systematic Biology, 57, 257-268.

Olmstead, R.G., dePamphilis, C.W., Wolfe, A.D., Young, N.D., Elisons, W.J. \& Reeves, P.A. (2001) Disintegration of the Scrophulariaceae. American Journal of Botany, 88, $348-361$.

Philippe, H., Snell, E.A., Bapteste, E., Lopez, P., Holland, P.W.H. \& Casane, D. (2004) Phylogenomics of eukaryotes: impact of missing data on large alignments. Molecular Biology and Evolution, 21, 1740-1752.

Posada, D. (2008) jModelTest: phylogenetic model averaging. Molecular Biology and Evolution, 25, 1253-1256.

Rambaut, A. \& Drummond, A.J. (2009) Tracer v1.5.0. Available at: http://beast.bio.ed.ac.uk/Tracer.

Raven, P.H. (1973) The evolution of Mediterranean floras. Mediterranean type ecosystems: origin and structure (ed. by F. di Castri and H.A. Mooney), pp. 213-224. Springer, New York.

Ronquist, F. \& Huelsenbeck, J.P. (2003) MrBayes 3: Bayesian phylogenetic inference under mixed models. Bioinformatics, 19, 1572-1574.

Ronquist, F., Huelsenbeck, J.P. \& van der Mark, P. (2005) MrBayes 3.1 Manual, draft 5/ 26/2005. Available at: http://mrbayes.sourceforge.net/wiki/index.php/Manual. 
Rowley, D.L., Coddington, J.A., Gates, M.W., Norrbom, A.L., Ochoa, R.A., Vandenberg, N.J. \& Greenstone, M.H. (2007) Vouchering DNA-barcoded specimens: test of a nondestructive extraction protocol for terrestrial arthropods. Molecular Ecology Notes, 7, 915-924.

Schuster, M., Duringer, P., Ghienne, J.-F., Vignaud, P., Mackaye, H.T., Likius, A. \& Brunet, M. (2006) The age of the Sahara Desert. Science, 311, 821.

Stamatakis, A. (2006) RAxML-VI-HPC: maximum likelihood-based phylogenetic analyses with thousands of taxa and mixed models. Bioinformatics, 22, 2688-2690.

Stamatakis, A., Hoover, P. \& Rougemont, J. (2008) A rapid bootstrap algorithm for the RAxML web servers. Systematic Biology, 57, 758-771.

Tamura, K., Dudley, J., Nei, M. \& Kumar, S. (2007) MEGA4: Molecular Evolutionary Genetics Analysis (MEGA) software version 4.0. Molecular Biology and Evolution, 24, 1596-1599.

Thiv, M., Thulin, M., Hjertson, M., Kropf, M. \& Linder, H.P. (2010) Evidence for a vicariant origin of Macaronesian-Eritreo/Arabian disjunctions in Campylanthus Roth (Plantaginaceae). Molecular Phylogenetics and Evolution, 54, 607-616.

Thiv, M., Van Der Niet, T., Rutschmann, F., Thulin, M., Brune, T. \& Linder, H.P. (2011) Old-New World and trans-African disjunctions of Thamnosma (Rutaceae): intercontinental long-distance dispersal and local differentiation in the succulent biome. American Journal of Botany, 98, 76-87.

Thomas, R.H. (1994) Molecules, museums and vouchers. Trends in Ecology and Evolution, 9, 413-414.

Thorne, R.F. (1972) Major disjunctions in the geographic ranges of seed plants. Quarterly Review of Biology, 47, 365-411. 
Verdcourt, B. (1969) The arid corridor between the north-east and south-west areas of Africa. Palaeoecology of Africa, 4, 140-144.

Whitfield, J.B. \& Cameron, S.A. (1994) Museum policies concerning specimen loans for molecular systematic research. Molecular Phylogenetics and Evolution, 3, 268-270.

Wiens, J.J. (2006) Missing data and the design of phylogenetic analyses. Journal of Biomedical Informatics, 39, 34-42.

Wiens, J.J. \& Moen, D.S. (2008) Missing data and the accuracy of Bayesian phylogenetics. Journal of Systematics and Evolution, 46, 307-314.

Wiens, J.J. \& Morrill, M.C. (2011) Missing data in phylogenetic analysis: reconciling results from simulations and empirical data. Systematic Biology, 60, 719-731.

Wiens, J.J., Fetzner, J.W., Parkinson, C.L. \& Reeder, T.W. (2005) Hylid frog phylogeny and sampling strategies for speciose clades. Systematic Biology, 54, 778-807.

Wilkinson, M. (1995) Coping with abundant missing entries in phylogenetic inference using parsimony. Systematic Biology, 44, 501-514.

Wolsan, M. \& Sato, J.J. (2010) Effects of data incompleteness on the relative performance of parsimony and Bayesian approaches in a supermatrix phylogenetic reconstruction of Mustelidae and Procyonidae (Carnivora). Cladistics, 26, 168-194.

Yu, Y., Harris, A.J. \& He, X-J. (2010) S-DIVA (Statistical Dispersal-Vicariance Analysis): a tool for inferring biogeographic histories. Molecular Phylogenetics and Evolution, 56, 848-850. 


\section{SUPPORTING INFORMATION}

Additional Supporting Information may be found in the online version of this article:

Appendix S1 Field-sampled and archival specimens used in this study with GenBank accession numbers except for samples whose DNA was amplified for the short $16 \mathrm{~S}$ amplicons only.

Appendix S2 Supplementary figures. Leg of Gymnetron villosulum remounted on an entomological card after DNA extraction (Fig. S1), graph showing correlation between uncorrected pairwise distances of 16S rRNA and COII mitochondrial genes (Fig. S2), and Bayesian phylogenetic tree inferred from DNA sequences from five genes (Fig. S3).

Appendix S3 List of primers used in PCR and sequencing reactions.

\section{BIOSKETCHES}

Gerardo Hernández-Vera recently obtained his PhD at the University of East Anglia, UK, and is interested in molecular phylogenetic methods applied to studies of evolutionary ecology, biogeography, and speciation and diversification processes. Roberto Caldara, Ivo Toševski and Brent Emerson have been collaborating for several years, focusing on the taxonomy and evolutionary history of weevils within the tribe Mecinini (Curculionidae: Curculioninae).

Author contributions: B.E. conceived and led the project; R.C. and I.T. provided material and assisted with the manuscript and data collection; G.H.-V. analysed the data and wrote the manuscript; B.E. assisted with the manuscript and contributed as senior author.

Editor: Mark Carine 
Table 1 Summary statistics for the five sequenced genes and the $16 S$ short phylogenetically informative amplicons (SPIAs) of southern African and Palaearctic lineages of endophagous weevils within the genera Rhinusa and Gymnetron. Total aligned base pairs includes outgroup taxa, the number of variable sites relates to ingroup taxa only.

\begin{tabular}{lcccccc}
\hline & $C O I I$ & $16 S$ & $16 S$ SPIAs & $A K$ & $E F-1 \alpha$ & $18 S$ \\
\hline Aligned base pairs & $697^{\mathrm{a}}$ & 307 & 150 & $715^{\mathrm{b}}$ & $647^{\mathrm{c}}$ & 1577 \\
Variable sites & 397 & 130 & 78 & 178 & 143 & 37 \\
Parsimony informative & 372 & 104 & 67 & 132 & 118 & 30 \\
a 682 bp for Gy1018 & $(53.4 \%)$ & $(33.9 \%)$ & $(44.6 \%)$ & $(18.5 \%)$ & $(18.2 \%)$ & $(2 \%)$ \\
${ }^{\mathrm{b}} 423$ bp for Gy976; 382 bp for Gy977 \\
c 418 bp for Gy975 and Gy976; 628 for Gy967
\end{tabular}


Table 2 Estimated times to the most recent common ancestor (TMRCA) for nodes indicating divergence of southern African and Palaearctic lineages of endophagous weevils within the genera Rhinusa and Gymnetron.

\begin{tabular}{ccc}
\hline Node number & Mean $(\mathrm{Ma})$ & $\begin{array}{c}95 \% \text { HPD intervals } \\
(\mathrm{Ma})\end{array}$ \\
\hline I & 7.4 & $1.1-15.9$ \\
II & 11.6 & $4.2-20.1$ \\
III & 11.0 & $4.1-19.1$ \\
IV & 8.5 & $2.7-16.0$ \\
\hline
\end{tabular}

HPD, highest posterior density 


\section{FIGURE LEGENDS}

Figure 1 Bayesian phylogenetic tree of southern African and Palaearctic lineages of endophagous weevils within the genera Rhinusa and Gymnetron inferred from DNA sequences from five genes (COII, 16S, EF-1 $\alpha, A K$ and $18 S$ ) comprising $3943 \mathrm{bp}$. Bayesian posterior probabilities and maximum likelihood bootstrap values are shown above and below branches, respectively. Seven higher order lineages and well-supported clades are labelled A-G. Species of Gymnetron are highlighted in bold.

Figure 2 Bayesian phylogenetic tree of southern African and Palaearctic lineages of endophagous weevils within the genera Rhinusa and Gymnetron inferred from (1) DNA sequences from five genes (COII, $16 S, E F-1 \alpha, A K$ and $18 S$ ) comprising 3943 bp for 54 ingroup samples and three outgroup taxa, and (2) $150 \mathrm{bp}$ of nucleotide data corresponding to the $16 S$ short phylogenetically informative amplicons (SPIAs) sampled from 37 archival specimens and 11 degraded specimens (highlighted in grey). Species of Gymnetron are highlighted in bold. Green branches indicate species from southern Africa. Bayesian posterior probabilities $\geq 0.8$ and maximum likelihood bootstrap values $\geq 70 \%$ are shown above and below branches, respectively. Major groups are labelled A-L. Roman numerals indicate nodes for which divergence times are estimated between southern African and Palaearctic lineages (see Table 2). Pie charts indicate relative probabilities of alternative ancestral ranges mapped onto nodes of interest, (A) southern Africa, (B) Palaearctic. Branches for archival samples associated with no mutational events have been assigned zero length. 


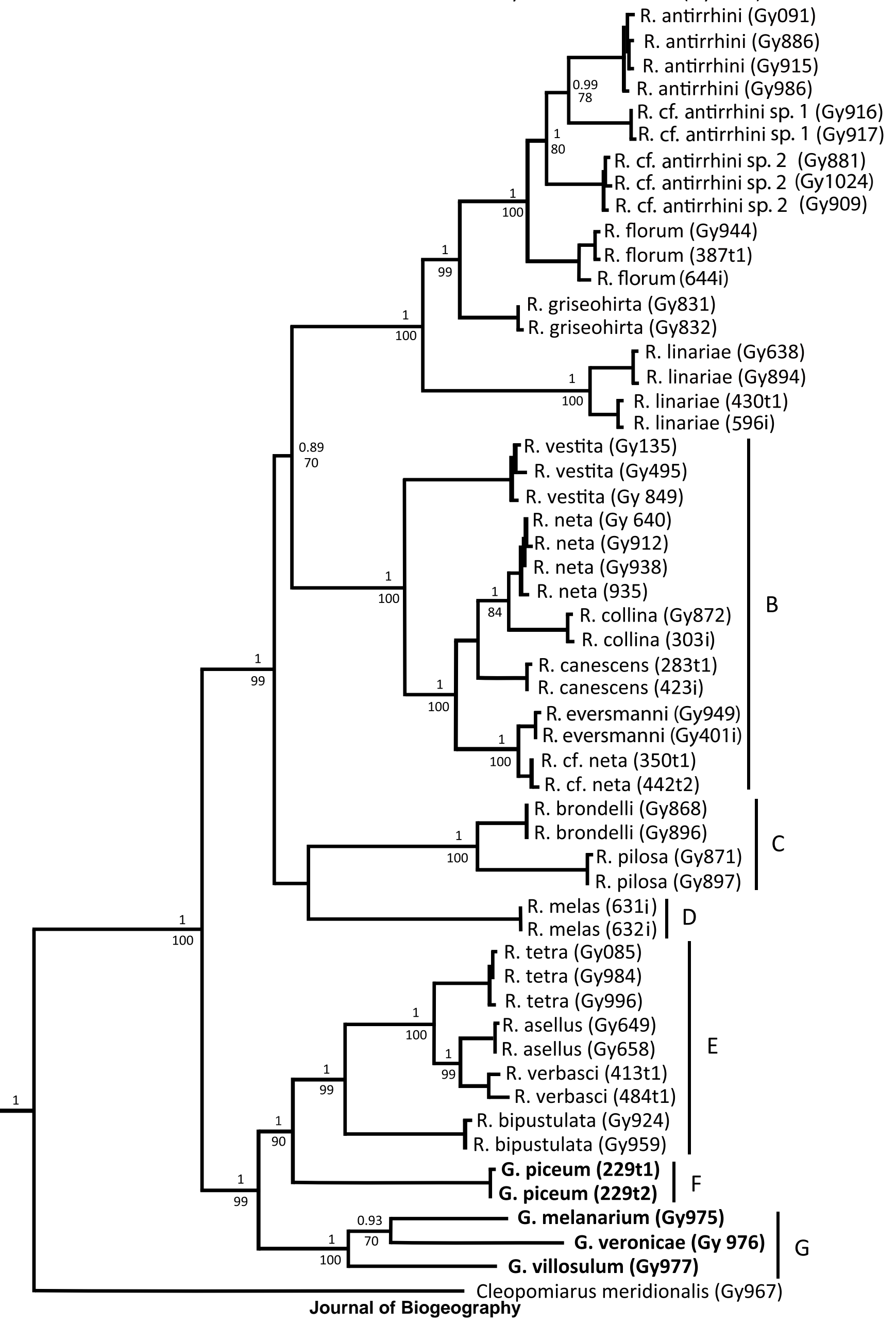




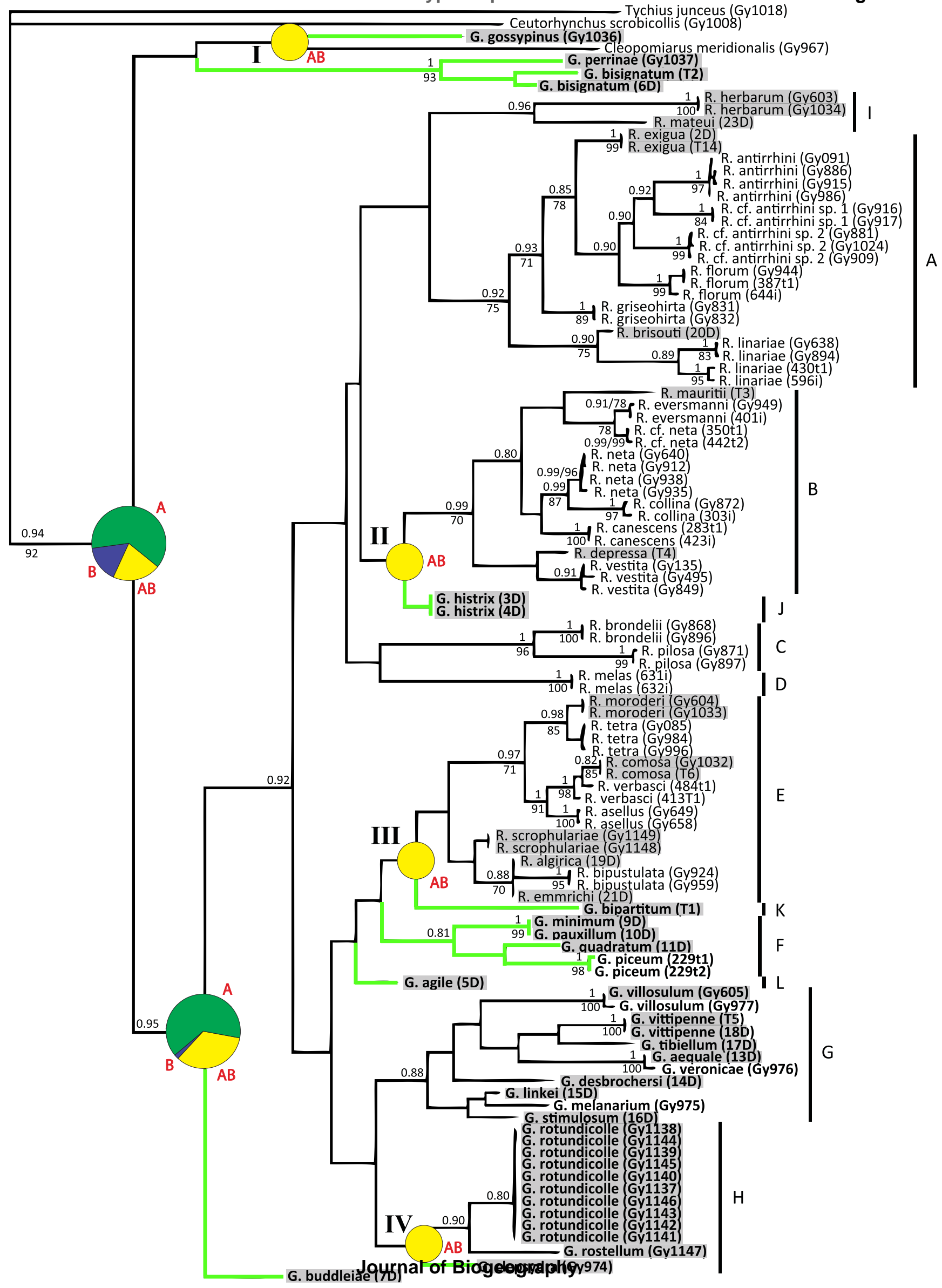




\title{
SUPPORTING INFORMATION
}

\section{Molecular phylogenetic analysis of archival tissue reveals the origin of a disjunct southern African-Palaearctic weevil radiation}

\author{
Gerardo Hernández-Vera, Roberto Caldara, Ivo Toševski and Brent C. Emerson \\ Journal of Biogeography
}

\begin{abstract}
Appendix S1 Field-sampled (a) and archival specimens (b) used in this study with GenBank accession numbers except for samples whose DNA was amplified for the short $16 \mathrm{~S}$ amplicons only. The full DNA sequence data matrix is available in TreeBase (http://treebase.org/, accession number S13611).
\end{abstract}

(a) Field-sampled specimens used in this study.

\begin{tabular}{|c|c|c|c|}
\hline Accession & Species $¥$ & $\begin{array}{l}\text { Country of } \\
\text { collection }\end{array}$ & $\begin{array}{l}\text { GenBank accession numbers (COII, } \\
16 S, A K, 18 S \text { and } E F-1 \alpha \text {, respectively) }\end{array}$ \\
\hline Gy085 & Rhinusa tetra & Spain & $\begin{array}{c}\text { JX455791, JX455766, JX091173, } \\
\text { JX091117, JX091252 }\end{array}$ \\
\hline Gy091 & R. antirrhini & Germany & $\begin{array}{c}\text { JX455792, JX455767, JX091174, } \\
\text { JX091118, HM007271 }\end{array}$ \\
\hline Gy135 & R. vestita & Portugal & $\begin{array}{c}\text { JX455793, JX455768, JX091175, } \\
\text { JX091119, JX091253 }\end{array}$ \\
\hline Gy495 & R. vestita & France & $\begin{array}{c}\text { JX455794, JX091086, JX091176, } \\
\text { JX091120, JX091254 }\end{array}$ \\
\hline Gy638 & R. linariae & Switzerland & $\begin{array}{c}\text { JX455795, JX455769, JX091177, } \\
\text { JX091121, JX091255 }\end{array}$ \\
\hline Gy640 & R. neta & Switzerland & $\begin{array}{c}\text { JX455796, JX455770, JX091178, } \\
\text { JX091122, JX091256 }\end{array}$ \\
\hline Gy649 & R. asellus & Spain & $\begin{array}{c}\text { JX455797, JX455771, JX091179, } \\
\text { JX091123, JX091257 }\end{array}$ \\
\hline Gy658 & R. asellus & Germany & $\begin{array}{c}\text { JX455798, JX455772, JX091180, } \\
\text { JX091124, JX091258 }\end{array}$ \\
\hline Gy831 & R. griseohirta & Spain & $\begin{array}{c}\text { JX455799, JX455773, JX091181, } \\
\text { JX091125, HM007274 }\end{array}$ \\
\hline Gy832 & R. griseohirta & Spain & $\begin{array}{c}\text { JX455800, JX091087, JX091182, } \\
\text { JX091126, JX091259 }\end{array}$ \\
\hline Gy849 & R. vestita & Spain & $\begin{array}{c}\text { EU073386, JX091088, JX091183, } \\
\text { JX091127, JX091260 }\end{array}$ \\
\hline Gy868 & R. brondelii & Serbia & $\begin{array}{c}\text { JX455801, JX091089, JX091184, } \\
\text { JX091128, JX091261 }\end{array}$ \\
\hline Gy871 & R. pilosa & Romania & $\begin{array}{c}\text { JX455802, JX091090, JX091185, } \\
\text { JX091129, JX091262 }\end{array}$ \\
\hline
\end{tabular}




\begin{tabular}{|c|c|c|c|}
\hline Accession & Species $\ddagger$ & $\begin{array}{l}\text { Country of } \\
\text { collection }\end{array}$ & $\begin{array}{l}\text { GenBank accession numbers (COII, } \\
16 S, A K, 18 S \text { and } E F-1 \alpha, \text { respectively) }\end{array}$ \\
\hline Gy872 & R. collina & Serbia & $\begin{array}{c}\text { JX455803, JX455774, JX091186, } \\
\text { JX091130, JX091263 }\end{array}$ \\
\hline Gy881 & R. cf. antirrhini sp. 2 & Serbia & $\begin{array}{c}\text { HM007235, JX455775, JX091187, } \\
\text { JX091131, JX091264 }\end{array}$ \\
\hline Gy886 & R. antirrhini & UK & $\begin{array}{l}\text { HM007229, JX455776, JX091188, } \\
\text { JX091132, HM007264 }\end{array}$ \\
\hline Gy894 & R. linariae & Serbia & $\begin{array}{c}\text { JX455804, JX455777, JX091189, } \\
\text { JX091133, JX091265 }\end{array}$ \\
\hline Gy896 & R. brondelii & Serbia & $\begin{array}{c}\text { JX455805, JX091091, JX091190, } \\
\text { JX091134, JX091266 }\end{array}$ \\
\hline Gy897 & R. pilosa & Serbia & $\begin{array}{c}\text { JX455806, JX091092, JX091191, } \\
\text { JX091135, JX091267 }\end{array}$ \\
\hline Gy909 & R. cf. antirrhini sp. 2 & Macedonia & $\begin{array}{c}\text { HM007237, JX455778, JX091192, } \\
\text { JX091136, HM007268 }\end{array}$ \\
\hline Gy912 & R. neta & France & $\begin{array}{c}\text { JX455807, JX455779, JX091193, } \\
\text { JX091137, JX091268 }\end{array}$ \\
\hline Gy915 & R. antirrhini & Spain & $\begin{array}{c}\text { HM007231, JX455780, JX091194, } \\
\text { JX091138, JX091269 }\end{array}$ \\
\hline Gy916 & R. cf. antirrhini sp. 1 & Serbia & $\begin{array}{l}\text { HM007232, JX091093, JX091195, } \\
\text { JX091139, HM007272 }\end{array}$ \\
\hline Gy917 & R. cf. antirrhini sp. 1 & Serbia & $\begin{array}{c}\text { JX455808, JX455781, JX091196, } \\
\text { JX091140, JX091270 }\end{array}$ \\
\hline Gy924 & R. bipustulata & Italy & $\begin{array}{c}\text { JX455809, JX455782, JX091197, } \\
\text { JX091141, JX091271 }\end{array}$ \\
\hline Gy935 & R. neta & Macedonia & $\begin{array}{c}\text { JX455810, JX455783, JX091198, } \\
\text { JX091142, JX091272 }\end{array}$ \\
\hline Gy938 & R. neta & Serbia & $\begin{array}{c}\text { JX455811, JX455784, JX091199, } \\
\text { JX091143, JX091273 }\end{array}$ \\
\hline Gy944 & R. florum & Serbia & $\begin{array}{c}\text { HM007233, JX455785, JX091200, } \\
\text { JX091144, HM007275 }\end{array}$ \\
\hline Gy949 & R. eversmanni & Romania & $\begin{array}{c}\text { JX091229, JX455786, JX091201, } \\
\text { JX091145, JX091274 }\end{array}$ \\
\hline Gy959 & R. bipustulata & Italy & $\begin{array}{c}\text { JX455812, JX455787, JX091202, } \\
\text { JX091146, JX091275 }\end{array}$ \\
\hline Gy984 & R. tetra & Serbia & $\begin{array}{c}\text { JX455813, JX091094, JX091203, } \\
\text { JX091147, JX091276 }\end{array}$ \\
\hline Gy986 & R. antirrhini & Serbia & $\begin{array}{l}\text { HM007230, JX455788, JX091204, } \\
\text { JX091148, JX091277 }\end{array}$ \\
\hline Gy996 & R. tetra & Serbia & $\begin{array}{c}\text { JX455814, JX091095, JX091205, } \\
\text { JX091149, JX091278 }\end{array}$ \\
\hline Gy1024 & R. cf. antirrhini sp. 2 & Bulgaria & $\begin{array}{c}\text { JX455815, JX455789, JX091206, } \\
\text { JX091150, HM007277 }\end{array}$ \\
\hline $283 \mathrm{t} 1$ & $R$. canescens & Italy & $\begin{array}{c}\text { JX091230, JX091096, JX091207, } \\
\text { JX091151, JX091279 }\end{array}$ \\
\hline
\end{tabular}




\begin{tabular}{|c|c|c|c|}
\hline Accession & Species $\ddagger$ & $\begin{array}{l}\text { Country of } \\
\text { collection }\end{array}$ & $\begin{array}{l}\text { GenBank accession numbers (COII, } \\
16 S, A K, 18 S \text { and } E F-1 \alpha, \text { respectively) }\end{array}$ \\
\hline $229 \mathrm{t} 1$ & Gymnetron piceum & South Africa & $\begin{array}{c}\text { JX091231, JX091097, JX091208, } \\
\text { JX091152, JX091280 }\end{array}$ \\
\hline $229 \mathrm{t} 2$ & G. piceum & South Africa & $\begin{array}{c}\text { JX091232, JX091098, JX091209, } \\
\text { JX091153, JX091281 }\end{array}$ \\
\hline $350 \mathrm{t} 1$ & $R$. cf. neta & Turkey & $\begin{array}{c}\text { JX091233, JX091099, JX091210, } \\
\text { JX091154, JX091282 }\end{array}$ \\
\hline $387 \mathrm{t} 1$ & R. florum & Macedonia & $\begin{array}{c}\text { JX091234, JX091100, JX091211, } \\
\text { JX091155, JX091283 }\end{array}$ \\
\hline $413 \mathrm{t} 1$ & R. verbasci & Macedonia & $\begin{array}{c}\text { JX091235, JX091101, JX091212, } \\
\text { JX091156, JX091284 }\end{array}$ \\
\hline $430 \mathrm{t} 1$ & R. linariae & Turkey & $\begin{array}{c}\text { JX091236, JX091102, JX091213, } \\
\text { JX091157, JX091285 }\end{array}$ \\
\hline $484 \mathrm{t} 1$ & R. verbasci & Macedonia & $\begin{array}{c}\text { JX091237, JX091103, JX091214, } \\
\text { JX091158, JX091286 }\end{array}$ \\
\hline $442 \mathrm{t} 2$ & $R$. cf. neta & Turkey & $\begin{array}{c}\text { JX091238, JX091104, JX091215, } \\
\text { JX091159, JX091287 }\end{array}$ \\
\hline $303 \mathrm{i}$ & R. collina & Turkey & $\begin{array}{c}\text { JX091239, JX091105, JX091216, } \\
\text { JX091160, JX091288 }\end{array}$ \\
\hline $401 \mathrm{i}$ & R. eversmanni & Serbia & $\begin{array}{c}\text { JX091240, JX091106, JX091217, } \\
\text { JX091161, JX091289 }\end{array}$ \\
\hline $423 \mathrm{i}$ & $R$. canescens & Italy & $\begin{array}{c}\text { JX091241, JX091107, JX091218, } \\
\text { JX091162, JX091290 }\end{array}$ \\
\hline $596 \mathrm{i}$ & R. linariae & Turkey & $\begin{array}{c}\text { JX091242, JX091108, JX091219, } \\
\text { JX091163, JX091291 }\end{array}$ \\
\hline $631 \mathrm{i}$ & R. melas & Serbia & $\begin{array}{c}\text { JX091243, JX091109, JX091220, } \\
\text { JX091164, JX091292 }\end{array}$ \\
\hline $632 \mathrm{i}$ & R. melas & Serbia & $\begin{array}{c}\text { JX091244, JX091110, JX091221, } \\
\text { JX091165, JX091293 }\end{array}$ \\
\hline $644 \mathrm{i}$ & R. florum & Turkey & $\begin{array}{c}\text { JX091245, JX091111, JX091222, } \\
\text { JX091166, JX091294 }\end{array}$ \\
\hline Gy975 & G. melanarium & UK & $\begin{array}{c}\text { JX091246, JX091112, JX091223, } \\
\text { JX091167, JX091295 }\end{array}$ \\
\hline Gy976 & G. veronicae & Italy & $\begin{array}{c}\text { JX091247, JX091113, JX091224, } \\
\text { JX091168, JX091296 }\end{array}$ \\
\hline Gy977 & G. villosulum & Italy & $\begin{array}{c}\text { JX091248, JX091114, JX091225, } \\
\text { JX091169, JX091297 }\end{array}$ \\
\hline Gy1138 & G. rotundicolle & Italy & \\
\hline Gy1139 & G. rotundicolle & Italy & \\
\hline Gy1140 & G. rotundicolle & Italy & \\
\hline Gy1146 & G. rotundicolle & Italy & \\
\hline Gy1145 & G. rotundicolle & Italy & \\
\hline Gy1144 & G. rotundicolle & Italy & \\
\hline Gy1143 & G. rotundicolle & Italy & \\
\hline Gy1142 & G. rotundicolle & Italy & \\
\hline Gy1141 & G. rotundicolle & Italy & \\
\hline
\end{tabular}




\begin{tabular}{|c|c|c|c|}
\hline Accession & Species $\ddagger$ & $\begin{array}{l}\text { Country of } \\
\text { collection }\end{array}$ & $\begin{array}{l}\text { GenBank accession numbers (COII, } \\
16 S, A K, 18 S \text { and } E F-1 \alpha \text {, respectively) }\end{array}$ \\
\hline Gy1137 & G. rotundicolle & Italy & \\
\hline Gy1147 & G. rostellum & Italy & \\
\hline Gy967 & $\begin{array}{l}\text { Cleopomiarus } \\
\text { meridionalis }\end{array}$ & Italy & $\begin{array}{c}\text { JX091249, JX091115, JX091226, } \\
\text { JX091170, JX091298 }\end{array}$ \\
\hline § Gy1008 & $\begin{array}{r}\text { Ceutorhynchus } \\
\text { scrobicollis }\end{array}$ & Germany & $\begin{array}{c}\text { JX091250, JX091116, JX091227, } \\
\text { JX091171, JX091299 }\end{array}$ \\
\hline § Gy1018 & Tychius junceus & Spain & $\begin{array}{c}\text { JX091251, JX455790, JX091228, } \\
\text { JX091172, JX091300 }\end{array}$ \\
\hline
\end{tabular}

$\S$ Outgroup taxa.

*Samples with comparatively weak PCR products that did not generate readable sequence chromatograms.

¥ Specimens are deposited within the collection of Roberto Caldara. 
(b) Archival specimens used in this study.

\begin{tabular}{|c|c|c|c|}
\hline Accession & Species & Country & Year of collection \\
\hline Gy1036 & G. gossypinus & South Africa & N.A. \\
\hline Gy603 & R. herbarum & N.A. & N.A. \\
\hline Gy604 & R. moroderi & N.A. & N.A. \\
\hline Gy605 & G. villosulum & N.A. & N.A. \\
\hline Gy1032 & R. comosa & N.A. & N.A. \\
\hline Gy1034 & R. herbarum & France & N.A. \\
\hline Gy1037 & G. perrinae & South Africa & N.A. \\
\hline Gy1149 & R. scrophulariae & United Arab Emirates & N.A. \\
\hline Gy1148 & R. scrophulariae & United Arab Emirates & N.A. \\
\hline $\mathrm{T} 1$ & G. bipartitum & South Africa & 1985 \\
\hline $\mathrm{T} 3$ & R. mauritii & Morocco & 2008 \\
\hline $\mathrm{T} 4$ & R. depressa & Morocco & N.A. \\
\hline $\mathrm{T} 5$ & G. vittipenne & Armenia & 2001 \\
\hline $\mathrm{T} 6$ & R. comosa & Turkey & 1986 \\
\hline $\mathrm{T} 2$ & G. bisignatum & South Africa & 1987 \\
\hline $6 \mathrm{D}$ & G. bisignatum & South Africa & 1990 \\
\hline $2 \mathrm{D}$ & R. exigua & Turkey & 2003 \\
\hline $3 \mathrm{D}$ & G. hystrix & South Africa & 1991 \\
\hline $4 \mathrm{D}$ & G. hystrix & South Africa & 1991 \\
\hline $5 \mathrm{D}$ & G. agile & South Africa & 2002 \\
\hline $7 \mathrm{D}$ & G. buddleiae & South Africa & 1993 \\
\hline $9 \mathrm{D}$ & G. minimum & South Africa & 2006 \\
\hline $10 \mathrm{D}$ & G. pauxillum & South Africa & 2005 \\
\hline $11 \mathrm{D}$ & G. quadratum & South Africa & 2009 \\
\hline $13 \mathrm{D}$ & G. aequale & Turkey & 1999 \\
\hline $14 \mathrm{D}$ & G. desbrochersi & Russia & 1990 \\
\hline $15 \mathrm{D}$ & G. linkei & Turkey & 2002 \\
\hline $16 \mathrm{D}$ & G. stimulosum & Czech Republic & 1954 \\
\hline $17 \mathrm{D}$ & G. tibiellum & Italy & 1997 \\
\hline $18 \mathrm{D}$ & G. vittipenne & Armenia & 1987 \\
\hline $19 \mathrm{D}$ & R. algirica & Tunisia & 2006 \\
\hline $20 \mathrm{D}$ & R. brisouti & Kazakhstan & 2000 \\
\hline $21 \mathrm{D}$ & R. emmrichi & Turkmenistan & 1991 \\
\hline $23 \mathrm{D}$ & R. mateui & Tunisia & 1998 \\
\hline T14 & R. exigua & Turkey & 1996 \\
\hline Gy1033 & R. moroderi & N.A. & N.A. \\
\hline Gy974 & G. clepsydra & South Africa & N.A. \\
\hline *Gy1035 & G. oxystomoides & South Africa & N.A. \\
\hline$* 1 \mathrm{D}$ & R. dieckmanni & Bulgaria & 1958 \\
\hline$* 8 \mathrm{D}$ & G. bipartitum & South Africa & 1986 \\
\hline$* 12 \mathrm{D}$ & G. simulator & South Africa & 1983 \\
\hline$* 22 \mathrm{D}$ & R. littorea & France & N.A. \\
\hline
\end{tabular}

N.A. Not available. 
Appendix S2 Supplementary figures.

Figure S1 Leg of Gymnetron villosulum remounted on an entomological card after DNA extraction.

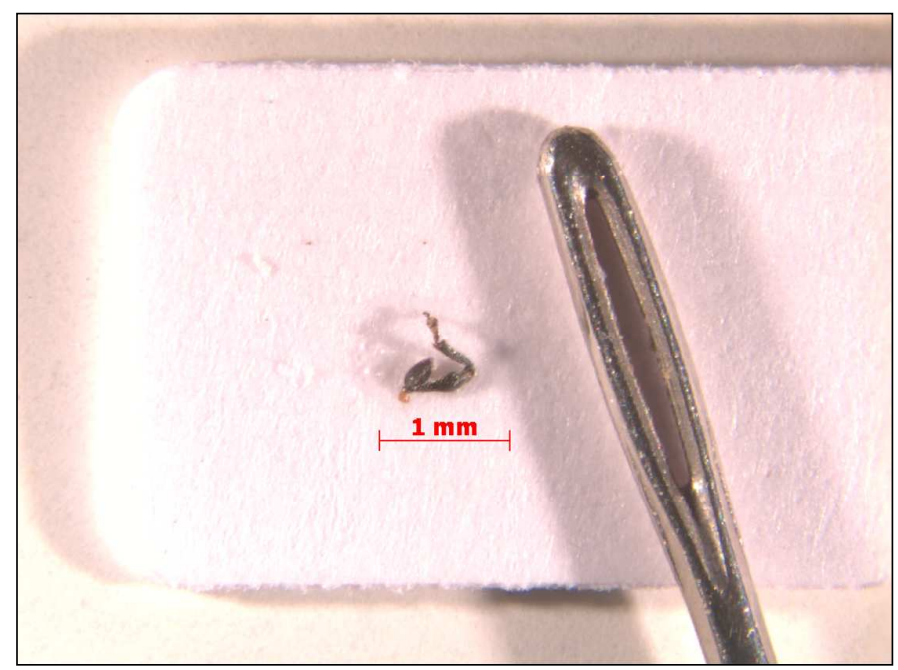

Figure S2 Graph of the correlation between uncorrected pairwise distances of the mitochondrial genes 16S ribosomal RNA $(16 S)$ and cytochrome $c$ oxidase subunit II (COII).

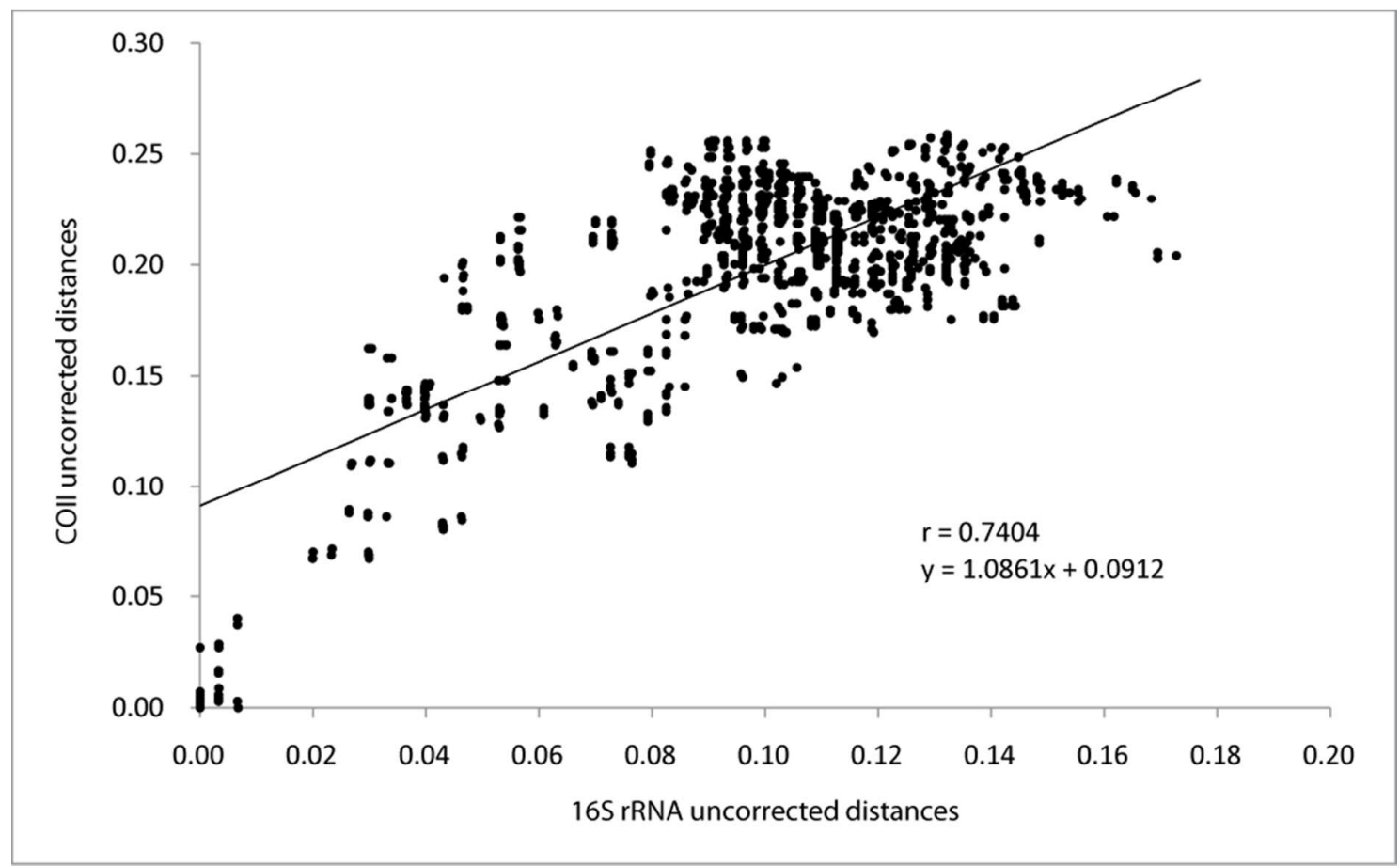


Figure S3 Bayesian phylogenetic tree of southern African and Palaearctic lineages of endophagous weevils within the genera Rhinusa and Gymnetron inferred from a data set of five gene DNA sequences (COII, 16S, EF-1 $\alpha, A K$ and $18 S$ ) comprising 3943 bp. Nucleotide data for highlighted taxa were reduced to $150 \mathrm{bp}$ corresponding to the $16 \mathrm{~S}$ short phylogenetically informative amplicons (SPIAs). Posterior probabilities are shown above branches and major groups are indicated $(A-G)$.

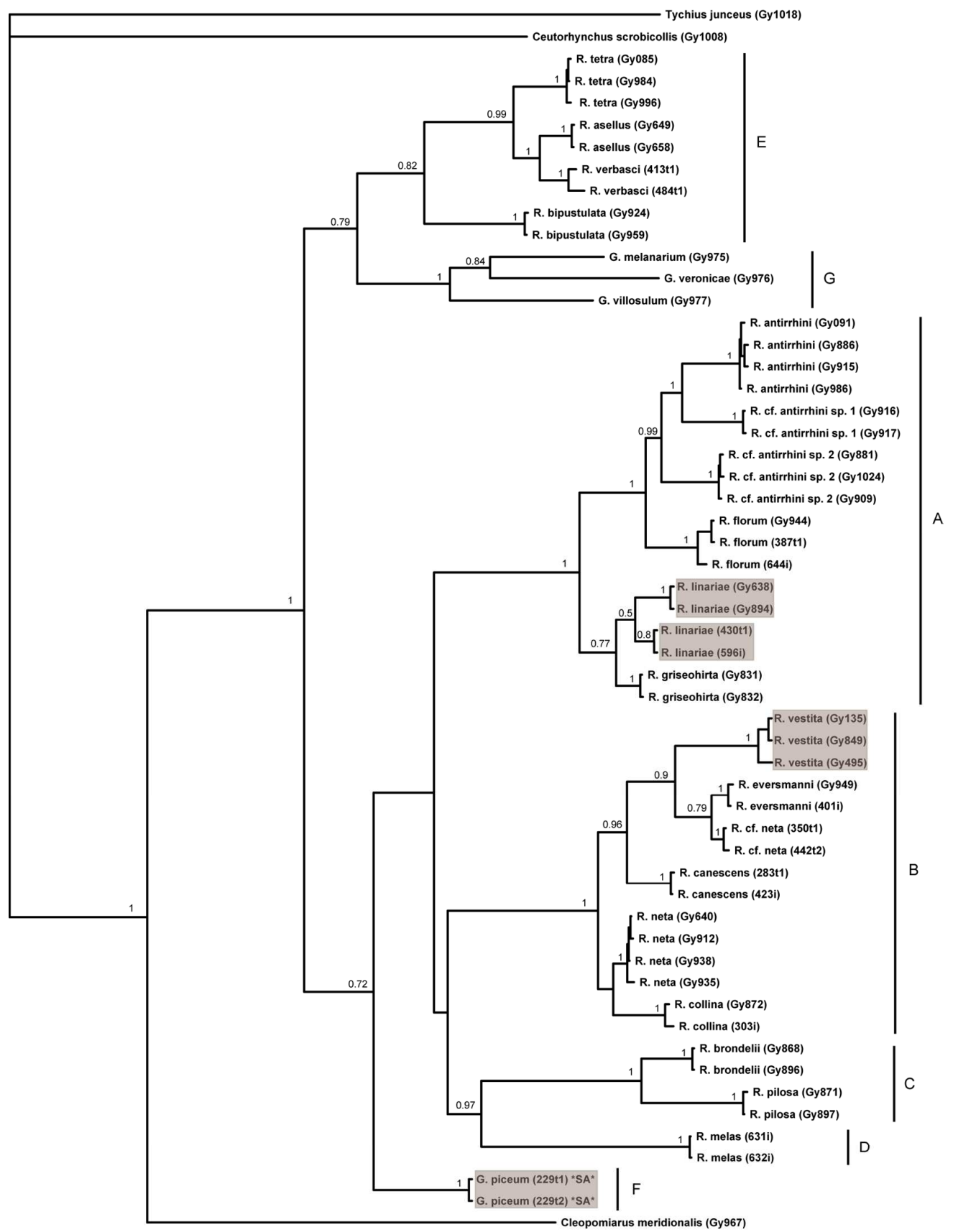


Appendix S3 Primers used in the amplification of nuclear and mitochondrial gene fragments: arginine kinase $(A K), 18 \mathrm{~S}$ ribosomal RNA (18S), elongation factor-1 $\alpha(E F 1-\alpha)$, cytochrome $c$ oxidase subunit II (COII) and 16S ribosomal RNA (16S).

\begin{tabular}{lllc}
\hline Gene & \multicolumn{1}{c}{ Name of } \\
primer & \multicolumn{1}{c}{ Sequence } & Amplicon \\
length (bp)
\end{tabular}

$(\mathrm{f})=$ forward reading, $(\mathrm{r})=$ reverse reading. [ ] = M13 adaptor sequence. 